\title{
SEED SOWING ORIENTATION RELATED TO SEED COAT ADHERENCE ON WATERMELON
}

\author{
Marcos Altomani Neves Dias ${ }^{1}$, Dial Sugianto ${ }^{2}$, Nihat Guner ${ }^{3}$, Mohammed Hassan $^{2}$ \\ ${ }^{1}$ B.Sc, Graduate student in Crop Science, University of São Paulo, Piracicaba, Brazil - Rua Frederico Ozanan, 112. Sertãozinho- \\ SP. CEP 14160-200. Email: marcosaltomani@hotmail.com \\ ${ }^{2}$ Watermelon technical assistants, B.Sc, Sakata Seed America Inc., Fort Myers, Florida, United States; \\ ${ }^{3}$ Watermelon Breeder, D.Sc, Sakata Seed America Inc., Fort Myers, Florida, United States.
}

\begin{abstract}
Watermelon (Citrullus lanatus (Thunb.) Matsum \& Nakai) seedlings generally present issues regarding to seed coat adherence to cotyledons at the emergence stage. In this case, the seed coat acts as a barrier for seedling development, which may result in stretched or malformed seedlings. Therewith, this study was carried out to evaluate the effects of seed orientation in the substrate on seedling emergence and growth, and also to evaluate the effect on seed coat adherence. Diploid, triploid and tetraploid watermelon seeds were used in this study. The treatments were composed of four seed lots and three different seed orientations at sowing: hilum pointed upwards (HUp), hilum pointed downwards (HDown) and hilum pointed horizontally (HHor). The evaluations consisted of: seedling emergence, seedling speed index, seedling height, seedling dry mass and seed coat adherence to cotyledons. HUp presented lower results for seed coat adherence to cotyledons, but negatively interfered on seedlings emergence and growth. In general, the treatment HHor presented the most satisfactory results, even though it did not solve the seed coat adherence issue.
\end{abstract}

Key words: diploid seeds, triploid seeds, tetraploid seeds, seedling production, cucurbit seeds

\section{ORIENTAÇÃO DA SEMENTE RELACIONADA À ADERÊNCIA DO TEGUMENTO EM MELANCIA} RESUMO

Plântulas de melancias triplóides e tetraplóides geralmente apresentam problemas relacionados à aderência do tegumento das sementes aos cotilédones. Neste caso, o tegumento age como uma barreira para o desenvolvimento das plântulas, o que pode resultar em alongamento e malformação das mesmas. Com isso, este experimento objetivou avaliar os efeitos das diferentes orientações de sementes de melancia no substrato sob a emergência de plântulas, o crescimento das mesmas e a aderência do tegumento aos cotilédones. Sementes de melancia diplóide, triplóide e tetraplóide foram usadas neste estudo. Os tratamentos foram compostos de quatro lotes e três orientações de sementes na semeadura: hilo voltado para cima (Hup), hilo voltado para baixo (HDown) e hilo posicionado horizontalmente (HHor). As avaliações consistiram em: emergência, índice de velocidade de emergência, altura de plântulas, massa de matéria seca de plântulas e aderência do tegumento aos cotilédones. Hup apresentou as menores porcentagens de aderência do tegumento aos cotilédones, mas prejudicou a emergência e desenvolvimento das plântulas. Em geral, o tratamento HHor apresentou os resultados mais safisfatórios, apesar de não reduzir o problema da aderência dos tegumentos.

Palavras-chave: sementes diplóides, sementes triplóides, sementes tetraplóides, produção de plântulas, cucurbitáceas 


\section{INTRODUCTION}

Watermelon is produced mainly for fresh fruit market, with countries such as China, Turkey, Russia, Iran and Brazil being the most important growers, respectively (FAOSTAT, 2007). Seedless watermelon has increased in preference by consumers, and in United States as an example, the seedless fruits corresponds to over $90 \%$ on total commercialization (SARGENT \& MAYNARD, 2009).

For seedless fruits obtainment, there is a need of tetraploid and triploid seeds (KIHARA, 1951); the first is used as parental, and the second is destined for commercial purposes. Both present thicker structures when compared to diploid seeds (SUN, 2009). Jaskani et al., (2005) attributed characteristics such as thicker leaves, higher chlorophyll content, thicker stems and higher leaf area index to tetraploid plants, when compared to diploid. Castro et $a l .$, (2006) reinforced that ploidy is related to seed size, affirming that higher ploidy results in sizing increase.

Thus, polyploidy on watermelon seeds frequently lead to problems regarding to germination and vigor, mainly due to a thicker seed coat, poor embryo vigor and higher moisture content (MAYNARD, 1989; GRANGE et al., 2000; GRANGE et al., 2003; MAYNARD, 2001; JASKANI et al., 2004 and JASKANI et al., 2006). In addition, a higher percentage of seedlings emerge with the seed coat adhered to cotyledon, acting as a barrier for radicle protusion and further development. Sun (2009) suggests a manual removal of seed coat as a way to minimize problems caused by seed coat adherence. However, some disadvantages of this practice are: potential damage to plants, spread of diseases and higher labor dependence.

Seedling production is a crucial step for good stand establishment on watermelon crop. At this stage of growth, intensive cares are needed to obtain uniform, healthy and vigorous plants (MAYNARD, 2001). The improvement of production techniques at this stage is of high relevance, considering that are many environmental stresses and physiological issues that may affect the plants at initial growth stages (SUN, 2009). Seed sowing orientation plays an important role on seedling production; Bowers and Hayden (1972) studied this effect for beans; Cantliffe (1984) for cucumbers; Bosy and Aarssen (1995) for seven different species of herbaceous plants; Martins et al., (1999) for red-palmito, Robles et al., (2000) for lime, Silva et al., (2007) for Euterpe oleracea Mart.; Maynard (1989), Jaskani et al., (2004) and Jaskani et al., (2006) studied those effects for watermelon, describing that radicle pointed upwards resulted on lower adherence of seed coat to cotyledon leaves, with no improvements on seedling emergence.

Thus, according to some authors, the watermelon growers should sow with hilum pointed upwards, in order to avoid seed coat adherence. However, as observed previously by the authors of this study, that orientation of sowing may result in reduction of emergence and seedling quality. Based on these finds, this research was carried out to assess the best seed orientation for watermelon sowing.

\section{MATERIAL AND METHODS}

The experiment was carried out in a research station of Sakata Seed America Inc., located in Fort Myers, Florida, United States, during the summer of 2010. Four seed lots were used: LOT A (commercial hybrid diploid, Sakata SWD8307, nonprimed); LOT B (tetraploid parental seeds); LOT C (triploid non-commercial seed, nonprimed); LOT D (triploid commercial seed, Sakata "Triple 7", primed). 
The germination and seed moisture content of the seed lots were assessed as described below.

Germination test: carried out with four replications of 50 seeds per lot, on blotter paper watered with 2,5 times the dry weight of the paper. The counting of normal and abnormal seedlings occurred at the $4^{\text {th }}$ and $14^{\text {th }}$ day after sowing (ISTA, 2004).

Seed moisture content: two samples of $20 \mathrm{~g}$ each were previously weighed on a $0,001 \mathrm{~g}$ accuracy scale, and placed in the oven at $105^{\circ} \mathrm{C}$, for 24 hours. Afterward, the initial moisture was determined based on the dry weight of the samples, and the results expressed in percentage.

The treatments consisted of three different seed orientations at sowing: hilum pointed upwards (HUp); hilum pointed downwards (HDown) and hilum pointed horizontally (HHor). The sowings occurred on polystyrene trays, with four replications of 32 seeds per lot in each treatment, totalizing 48 entries randomly distributed among twelve trays. The sowing depth consisted of one centimeter below soil surface. Commercial substrate for watermelon (Fafard 2 Mix) was used and the seeds were uniformly covered with perlite. Afterward, the trays were placed in a dark chamber $\left(30^{\circ} \mathrm{C}, 90 \%\right.$ humidity $)$ for 48 hours. After this period, the trays were moved to a greenhouse.

The post-emergence evaluations are described as follows.

Seedling emergence: counting of emerged seedlings on the fourteenth day after sowing.

Seedling speed index: counting of emerged seedlings each day after the emergence started. The vigor index is given by the formula described by Maguire (1962), $\mathrm{GSI}=\mathrm{E} 1 / \mathrm{N} 1+\mathrm{E} 2 / \mathrm{N} 2+\ldots+\mathrm{En} / \mathrm{Nn}$; where "En" is the number of emerged seedlings (higher than $1 \mathrm{~cm}$ ) and " $\mathrm{Nn}$ " corresponds to the number of days after sowing.
Seed coat adherence: daily counting of seedlings emerged with adhered seed coat, until the end of emergence test.

Seedlings height: at the $14^{\text {th }}$ day after sowing the seedlings height were determined with a ruler, in millimeters. The measurements were taken from the substrate surface to the apical meristem.

Seedlings dry mass: at the $14^{\text {th }}$ day after sowing, the seedlings were cut flush with the soil surface, and oven dried at $65^{\circ} \mathrm{C}$ until constant mass. Afterward, the seedlings dry mass were determined by a $0,01 \mathrm{~g}$ analytical scale, with the values adjusted for the number of seedlings per entry.

Distorted stem: the number of seedlings that presented distortion in the stem at the $14^{\text {th }}$ day was counted on each entry, guided by the symptom shown on Figure 2.

The data of seedling emergence, emergence speed index, seedling dry mass, seedling height and seed coat adherence were analyzed by ANOVA and, in case of significance, the means were compared by Tukey test using SAS software (SAS, 2000). Data of germination was analyzed by means and standard mean error (SME).

\section{RESULTS AND DISCUSSION}

The germination test (Table 1) pointed lots $\mathrm{A}$ and $\mathrm{D}$ as having higher germination percentages, compared to lots $\mathrm{C}$ and D. In fact, the first ones were conditioned for commercial purposes, whilst lots $\mathrm{B}$ and $\mathrm{C}$ presented poor germination, as they were not destined for commercial use. Thus, considering that watermelon breeders and researchers in general are, in many situations, subjected to deal with low quality seeds from their germplasm, lots B and C were also considered appropriate to carry on this study, in order to represent the situations faced either by growers and researchers who deal with watermelon crop. 
The seed moisture content determined for lot A was 4,6\%, for Lot B was $8,9 \%$, for Lot $C$ was $5,8 \%$ and for Lot $D$ was $4,9 \%$. The differences in seed moisture among the seed lots were probably given by differences in drying and storage conditions of the seeds before the study.

For seedling emergence (SE), the lowest values were obtained by HUp, on all seed lots tested (Table 2), with lots $\mathrm{C}$ and $\mathrm{D}$ presenting significant results. It was not observed any difference on seedling emergence among HDown and HHor, with an exception for Lot C, where HDown showed a significant advantage compared to the other seed orientation treatments. Jaskani et al., (2006) verified that seed sowing orientation affected emergence percentages on watermelon crop, with some variations between genotypes.

Table 1. Germination percentages $(\mathrm{G})$ of the seed lots A (diploid, commercial), B (tetraploid, non-commercial), C (triploid, non-commercial) and D (triploid, commercial).

\begin{tabular}{ccc}
\hline LOT & G $(\boldsymbol{\%})$ & \\
\hline A & 84 & $\pm 0,40^{1}$ \\
B & 21 & $\pm 1,41$ \\
C & 37 & $\pm 1,29$ \\
D & 96 & $\pm 0,81$ \\
\hline
\end{tabular}

${ }^{1}$ Corresponds to the Standard Mean Error of four replications.

Table 2. Effects of three seed sowing orientations on watermelon: hilum pointed upwards (up), downwards (down) and horizontally (hor), on four watermelon seed lots (A, B, C and D). E (emergence); SSI (seedling speed index); SH (seedling height); SDM (seedling dry mass); SCA (seed coat adherence).

\begin{tabular}{|c|c|c|c|c|c|c|c|c|c|c|c|}
\hline Lot & Treatment & $\mathrm{E}(\%)$ & & SSI & & $\mathrm{SH}(\mathrm{cm})$ & & $\operatorname{SDM}(g)$ & & $\operatorname{SCA}(\%)$ & \\
\hline \multirow{3}{*}{$\mathbf{A}$} & up & $86,2 a^{1}$ & $\pm 0,04^{2}$ & $42,1 b$ & $\pm 2,18$ & $3,1 b c$ & $\pm 0,07$ & $0,60 \mathrm{bcd}$ & $\pm 0,02$ & $5,5 \mathrm{f}$ & $\pm 0,02$ \\
\hline & down & $91,5 \mathrm{a}$ & $\pm 0,04$ & $51,4 \mathrm{a}$ & $\pm 2,04$ & $3,9 \mathrm{a}$ & $\pm 0,15$ & $0,65 a b c$ & $\pm 0,05$ & $98,5 \mathrm{a}$ & $\pm 0,01$ \\
\hline & hor & $90,7 \mathrm{a}$ & $\pm 0,03$ & $47,7 \mathrm{ab}$ & $\pm 1,94$ & $3,9 a$ & $\pm 0,14$ & $0,75 a$ & $\pm 0,05$ & $76,2 b c$ & $\pm 0,10$ \\
\hline \multirow{3}{*}{ B } & up & $28,0 \mathrm{c}$ & $\pm 0,01$ & $13,0 \mathrm{ef}$ & $\pm 0,45$ & $3,7 \mathrm{a}$ & $\pm 0,08$ & $0,65 a b c$ & $\pm 0,04$ & $36,2 \mathrm{e}$ & $\pm 0,09$ \\
\hline & down & $35,0 \mathrm{c}$ & $\pm 0,07$ & $18,5 \mathrm{de}$ & $\pm 3,52$ & $3,8 \mathrm{a}$ & $\pm 0,10$ & $0,54 \mathrm{cde}$ & $\pm 0,02$ & $97,0 \mathrm{a}$ & $\pm 0,03$ \\
\hline & hor & $35,7 \mathrm{c}$ & $\pm 0,05$ & $17,3 \mathrm{de}$ & $\pm 2,18$ & $3,6 \mathrm{a}$ & $\pm 0,15$ & $0,54 \mathrm{cde}$ & $\pm 0,06$ & $56,7 \mathrm{~cd}$ & $\pm 0,08$ \\
\hline \multirow{3}{*}{$\mathbf{C}$} & up & $29,0 \mathrm{c}$ & $\pm 0,06$ & $9,9 \mathrm{ef}$ & $\pm 2,01$ & $2,7 \mathrm{~cd}$ & $\pm 0,11$ & $0,44 \mathrm{e}$ & $\pm 0,03$ & $38,5 \mathrm{de}$ & $\pm 0,11$ \\
\hline & down & $51,7 \mathrm{~b}$ & $\pm 0,05$ & $23,7 \mathrm{~cd}$ & $\pm 2,74$ & $3,1 \mathrm{cb}$ & $\pm 0,15$ & $\mathrm{o}, 47 \mathrm{e}$ & $\pm 0,02$ & $96,7 \mathrm{a}$ & $\pm 0,03$ \\
\hline & hor & $37,0 \mathrm{c}$ & $\pm 0,02$ & $14,7 \mathrm{ef}$ & $\pm 1,59$ & $3,2 \mathrm{~b}$ & $\pm 0,22$ & $0,52 \mathrm{e}$ & $\pm 0,05$ & $63,5 b c$ & $\pm 0,03$ \\
\hline \multirow{3}{*}{ D } & up & $59,0 \mathrm{~b}$ & $\pm 0,11$ & $27,0 \mathrm{c}$ & $\pm 4,54$ & $2,7 \mathrm{~d}$ & $\pm 0,15$ & $0,74 \mathrm{a}$ & $\pm 0,04$ & $41,0 \mathrm{de}$ & $\pm 0,13$ \\
\hline & down & $97,7 \mathrm{a}$ & $\pm 0,01$ & $52,7 \mathrm{a}$ & $\pm 2,40$ & $3,0 \mathrm{cb}$ & $\pm 0,21$ & $0,70 \mathrm{ab}$ & $\pm 0,05$ & $100,0 \mathrm{a}$ & - \\
\hline & hor & $95,5 \mathrm{a}$ & $\pm 0,02$ & $49,1 \mathrm{ab}$ & $\pm 1,48$ & $3,1 \mathrm{cb}$ & $\pm 0,14$ & $0,69 \mathrm{ab}$ & $\pm 0,03$ & $81,0 \mathrm{ab}$ & $\pm 0,04$ \\
\hline & $\mathrm{CV}(\%)^{3}$ & 8,38 & & 11,36 & & 7,98 & & 9,67 & & 14,83 & \\
\hline
\end{tabular}

${ }^{1}$ Means followed by the same letter on the column do not differ by Tukey test at $5 \%$ level of significance.

${ }^{2}$ Corresponds to the Standard Mean Error of four replications.

${ }^{3} \mathrm{CV}=$ coefficient of variance. 
The data of seedling speed index (SSI), shown in Table 2, are in line with the results previously described. For all seed lots analyzed, HUp presented the lowest SSI, with significant results for lots A, C and D. The SSI test, described by Maguire (1962), is a relevant vigor test, which is based on the ability of the seed lots to germinate and develop seedlings rapidly. The results provided by this experiment lead to the conclusion that modifying seed orientation may alter the results obtained from this test in watermelon.

When evaluating the results obtained from seedling height ( $\mathrm{SH})$, presented on Table 2, it is possible to affirm that HUp caused a reduction in stem growth, except for Lot B. That probably occurred because when radicle is emitted upwards, a phenomenon named gravitropism drives the root growth downwards (TAIZ \& ZEIGER, 2010). Significant results were obtained for Lot A, with HUp showing the lowest average of seedling height. In contrast, Cantliffe (1984) found that radicle end upwards on cucumber resulted on higher values of seedling dry mass, pointing to an improve in seedling development when hilum is pointed upwards.

Regarding to seed coat adherence (SCA) to the emerged cotyledons, with data in Table 2 and the symptom shown in Figure 1 , there were significant results for all lots analyzed, with HUp showing the lowest adherence percentages. Similar results were reported by Maynard (1989), Jaskani et al., (2004) and Jaskani et al., (2006). Comparing HHor and HDown for seed coat adherence, the first showed better results (lower adherence), for all lots evaluated, being significant for lots A, B and C. On Lot D, HDown showed $100 \%$ seed coat adherence, while HUp and HHor showed $41 \%$ and $81 \%$, respectively. Thus, it's reasonable to conclude, that HDown drastically amplified the incidence of seedlings presenting the seed coat adhered to cotyledons, whilst HHor tended to alleviate this adherence, and HUp significantly reduced the adherence.

Preliminary experiences in greenhouse and field, allowed the authors of this study to identify some weakening issues on watermelon seedlings, due to narrowing and distortions in the stems as shown in Figure 2. Sowing orientation was playing an important role on the appearance of these symptoms. With no exception, all the seedlings that presented these symptoms originated from HUp, with lot A presenting $40 \%$, lot B $57 \%$, lot C $35 \%$ and lot D $29 \%$ of seedlings with distortion and narrowing in the stems. The major problem attributed to this phenomenon is rupture in the stem along the transplant of the seedlings in the field. Moreover, that may negatively affect translocation of water and nutrients throughout the plants.

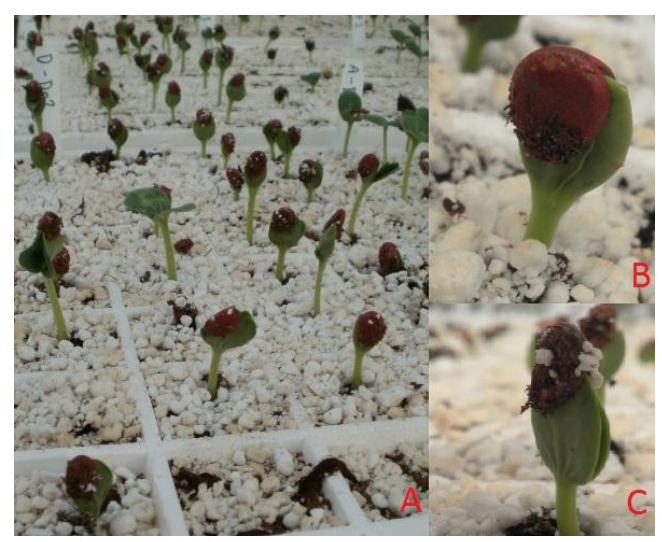

Figure 1. Seed coat adherence to cotyledons of triploid watermelon. 


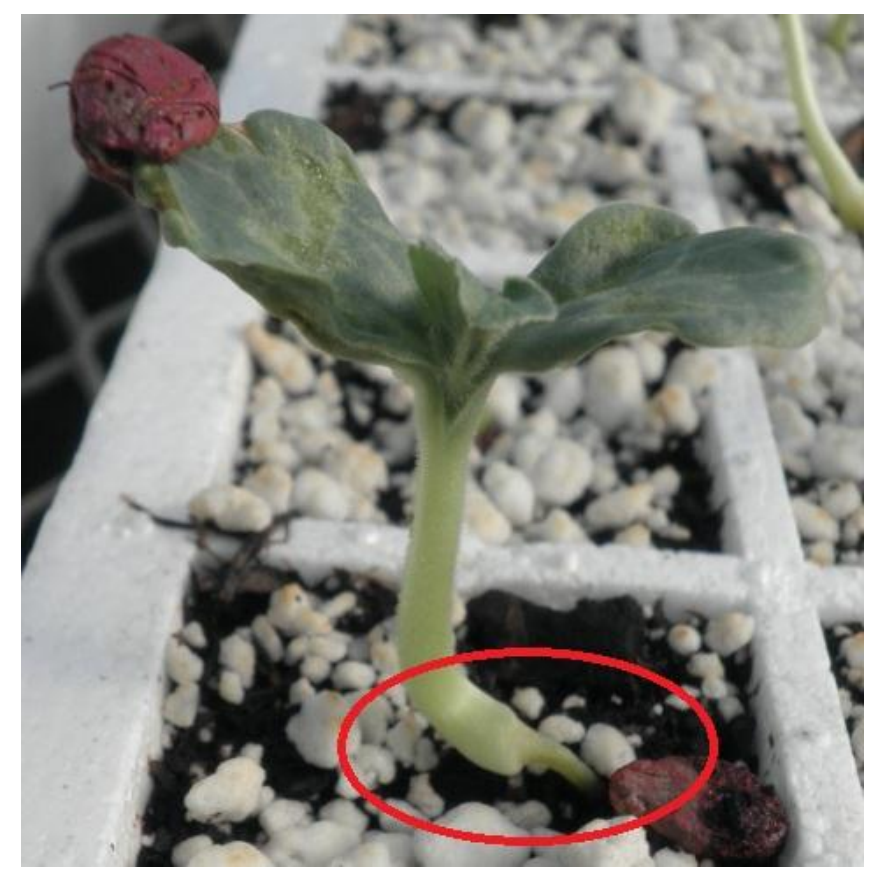

Figure 2. Distortion and narrowing symptoms in the stem, caused by seed sowing orientation with hilum pointed upwards.

Thus, this study shows that perhaps HUp reduced the seed coat adherence to cotyledons, it negatively affects seedlings emergence and growth. On the other hand, HDown intensified the seed coat adherence, and should be avoided. Therewith, another approach should be taken regarding this adherence issue, especially because it stills a major problem even in large scale commercial production. HHor should be recommended as the best seed sowing orientation for this crop, even though it does not solve the seed coat adherence issue.

\section{CONCLUSIONS}

Seed sowing orientation influences the seed coat adherence to cotyledons, seedling emergence and seedling development of diploid, triploid and tetraploid watermelon. HUp reduced the seed coat adherence to cotyledons, but negatively affected seedlings emergence and growth. HDown significantly intensified seed coat adherence to cotyledons. In general, HHor presented the most satisfactory results, even though it does not solve the seed coat adherence issue.

\section{ACKNOWLEDGMENTS}

The authors express their appreciation to Sakata Seed America, Inc. for the support given on this study.

\section{REFERENCES}

BOSY, J; AARSSEN, L. W. 1995. The effects of seed orientation on germination in a uniform environment: differential success without genetic or environmental variation. Journal of Ecology, v.83, p. 769-773.

BOWERS, S.A; HAYDEN, C.W. 1972. Influence of seed orientation on bean seedling emergence. Agronomy Journal, v.64, p. 736-738. 
CANTLIFFE, D. J. 1984. Seed orientation, seed quality and their effect on emergence and sex expression in cucumber. Proc. Fla. State. Hort. Soc., v.97, p. 174-176.

CASTRO, J; HÓDAR, J.A.; GÓMEZ, J.M. 2006. Seed Size. In: BASRA, A.S.(editor), Handbook of Seed Science and Technology. New York: The Haworth Press, 795p.

FAOSTAT (Food and Agriculture Organization of the United Nations). 2007. Available online at http://www.fao.org

GRANGE, S.; LESKOVAR, D.I.; PIKE, L.M.; COBB, B.G. 2000. Excess moisture and seed coat alteration influence germination of triploid watermelon. Hort Science, v.35, p. 1355-1356.

GRANGE, S.; LESKOVAR, D.I.; PIKE, L.M.; COBB, B.G. 2003. Seed coat structure and oxygen-enhanced environments affect germination of triploid watermelon. J. Amer. Soc. Hort. Sci., v.128, n.253-259.

ISTA (Internacional Seed Testing Association). 2004. Internacional Rules for Seed Testing, Fourth Edition. Zurich.

JASKANI, M.J; KWON, S.W.; KIM, E.J.; KO, B.R. 2004. Polyploidy affects fruit characteristics, seed morphology, and germination in watermelon. J. Kor. Soc. Hort. Sci. v.45, n.5, p.233-237.

JASKANI, M.J.; Kwon, S.W.; Kim, D.H. 2005. Comparative study on vegetative, reproductive and qualitative traits of seven diploids and tetraploids watermelon lines. Euphytica, n.145, p.259-268.

JASKANI, M.J.; KWON, S.W.; KIM, D.H.; ABBAS, H. 2006. Seed treatments and orientation affects germination and seedling emergence in tetraploid watermelon. 1951. Pak. J. Bot., v.38, n.1, p.89-98.

KIHARA, H. Triploid Watermelons. Proc. Amer. Soc. Hort. Sci. n.58, p.217-230.

MAGUIRE, J.D. 1962. Speed of germination aid in selection and evaluation for seedling emergence and vigor. Crop Science, Madison, v.2, n.2, p.176-77.

MARTINS, C.C; NAKAGAWA, J.; BOVI, M.L.A. 1999. Efeito da posição da semente no substrato e no crescimento inicial das plantas de palmito-vermelho. Revista Brasileira de Sementes, v.21, n.1, p.164-173.

MAYNARD, D.N. 1989. Triploid watermelon seed orientation affects seed coat adherence on emerged cotyledons. Hort Science, n.24, p.603-604.

MAYNARD, D. N. Watermelons: Characteristics, Production and Marketing. 2001. Alexandria: ASHS Press, 227p.

ROBLES, W.G.R; ARAÚJO, P.S.R.; MINAMI, K. 2000. Desenvolvimento de plântulas de limoeiro 'cravo' relacionado à posição de semeadura. Scientia Agricola, v.57, n.2, p.371-373.

SARGENT, S.A.; MAYNARD, D.N. 2009. Postharvest Biology and Technology of Cucurbits. In: JANICK, J. (editor) Horticultural Reviews, v.35, 529p. 
SAS Institute Inc. 2000. SAS/STAT. User's Guide, version 8.0. Cary.

SILVA E SILVA, B.M.; MÔRO, F.V.; SADER, R.; KOBORI, N.N. 2007. Influência da posição e da profundidade de semeadura nas plântulas de açaí. Revista Brasileira de Fruticultura, v. 29, n.1, 187-190.

SUN, X. 2009. China Seedless Watermelon Research and Application. China Agriculture Press, 116p.

TAIZ, L.; ZEIGER, E. 2010. Plant Physiology, $5^{\text {th }}$ Ed. Sunderland: Sinauer Associates, Inc., 782p. 